Review - Human and Animal Health

\title{
Walker-256 Tumor: Experimental Model, Implantation Sites and Number of Cells for Ascitic and Solid Tumor Development
}

\author{
Luane Aparecida do Amaral ${ }^{1}$ \\ https://orcid.org/0000-0002-1448-2472 \\ Gabriel Henrique Oliveira de Souza ${ }^{2}$ \\ Mirelly Romeiro Santos ${ }^{1}$ \\ https://orcid.org/0000-0002-1024-1540 \\ Yasmin Lany Ventura Said ${ }^{1}$ \\ Bruna Brandão de Souza ${ }^{1}$ \\ Rodrigo Juliano Oliveira ${ }^{3}$ \\ https://orcid.org/0000-0003-3514-3346
}

\section{Elisvania Freitas dos Santos ${ }^{4, *}$}

https://orcid.org/0000-0002-1528-6035

\begin{abstract}
${ }^{1}$ Federal University of Mato Grosso do Sul, Faculty of Medicine, Graduate Program in Health and Development in the Midwestern Region, Campo Grande, Mato Grosso do Sul, Brazil. ${ }^{2}$ Federal University of Mato Grosso do Sul, Graduating in Food Technology at the Faculty of Pharmaceutical Sciences, Food and Nutrition, Campo Grande, Mato Grosso do Sul, Brazil. ${ }^{3}$ Federal University of Mato Grosso do Sul, Faculty of Medicine, Program in Health and Development in the Midwestern Region, Stem Cell, Cell Therapy and Toxicological Genetics Research Centre, Maria Aparecida Pedrossian, University Hospital, Brazilian Hospital Services Company, Campo Grande, Mato Grosso do Sul, Brazil. ${ }^{4}$ Federal University of Mato Grosso do Sul, Associate Professor at the Faculty of Pharmaceutical Sciences, Food and Nutrition, Postgraduate Program in Health and Development in the Midwestern Region, Campo Grande, Mato Grosso do Sul, Brazil.
\end{abstract}

Received:2018.06.07; Accepted: 2019.03.25

* Correspondence: elisvania@gmail.com; Tel.: +55-67-81155325 (E.F.S.) 


\section{HIGHLIGHTS}

- Most common experimental tumor model to study cancer.

- Review of the main works that use the Walker-256 tumor.

- Definition of sites of Walker-256 tumor implantation.

- Usual quantity of tumoral cells to induce the ascitic and solid tumor.

Abstract: The Walker-256 tumor is an important experimental model that allow the development of therapies as the biological behavior of this tumor is similar that occur in humans. In front of the above considerations, the aim of this study was to describe the experimental model of Walker-256 tumor, identify the implantations sites as well as define a usual quantity of tumoral cells to induce the ascitic and solid tumor, according to the specialized literature. Were selected 45 articles using the keyword "Walker-256 tumor", free available. Were possible to observe that $58 \%(n=26)$ of the studies inoculate the tumor cells in the animals flank 33\% $(n=15)$ in the tibia bone, $7 \%(n=3)$ in the femur and $2 \%(n=1)$ in the paw. The major quantitates of cells used were $8 \times 10^{7}(20 \%), 1 \times 10^{5}(13 \%), 1 \times 10^{6}$ $(11 \%)$ and $2 \times 10^{7}(11 \%)$. After that, the site commonly used to inoculate was the flank and quantitate still a controversy, being $1 \times 10^{5}$ and $8 \times 10^{7}$ the concentrations more used.

Keywords: Walker-256 tumor; Cancer; Experimental model; Rats.

\section{GRAPHICAL ABSTRACT}

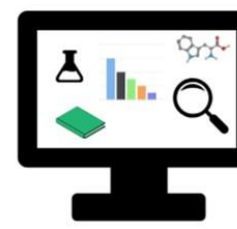

Researches

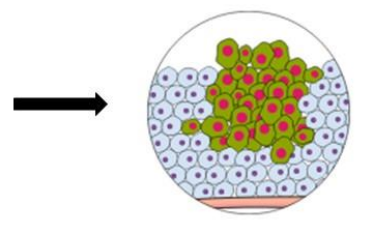

Walker-256 tumor

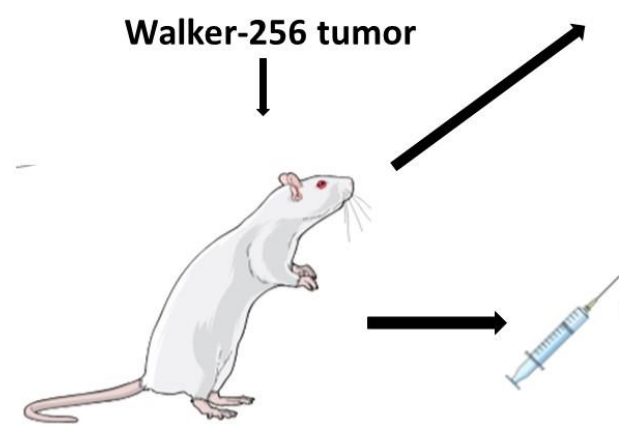

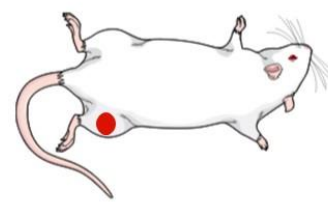

Common site

Flank

Cells for solid tumor

$8 \times 10^{7}$

$1 \times 10^{5}$ 


\section{INTRODUCTION}

Is expected that 14 million of people develop cancer each year, and this number must increase to more than 21 million until 2030. This disease is responsible for almost one in each six deaths worldwide. Each year, 8,8 million of people died from cancer especially in low income countries ${ }^{1}$.

Among the causes of death by cancer is cachexia, responsible by $20 \%$ of death. This complication in oncologic patients cooperate to a worse prognostic, lower survival, alterations quality of life, deterioration in functional capability, as well as significantly contribute to toxicity induced by chemotherapy ${ }^{2,3}$.

Is known that the conventional treatment for cancer is chemotherapy. However, it case diverse collateral effects and are not efficient in complete remission of tumor. Therefore, several studies are developed searching for new substances that can substitute the conventional method $4,5,6,7,8,9,10,11$. Thus, it is necessary to use experimental models that corresponds more to the reality of individuals affected by this disease.

Walker-256 tumor is a model that allow this situation. This model is possible to observe the three carcinogenesis stages: initiation, promotion and progression in a brief period of 12-16 days. In addition, the Walker-256 tumor exhibit aggressive biological behavior, locally invasive, with high metastasis capacity ${ }^{12,13}$.

This tumor is used in studies for breast cancer, bone and paw tumors, it has accelerated growth, causing cachexia and oxidative stress, and still has a high metabolic demand, similar to what occurs with cancer patients ${ }^{14}$.

The present study had as objective describe the experimental tumor model Walker-256, identify the implantation sites, as well as define a quantity of usual tumoral cells to induce the ascitic and solid tumor, according to the literature.

\section{MATERIAL AND METHODS}

Were included experimental studies that used the tumor model Walker-256 in this review. The search were performed by the Pubmed database, using the keyword: Walker-256. Were considered the articles free available, published between 2012 and July/2018. The exclusion criteria were: (1) do not fit in criteria described above; (2) literature review; (3) case study; (4) retrospective and observational studies; (5) do not describe quantitate of cells used for induce solid tumor.

The search resulted in 1253 articles, to extract the data were evaluated the titles and abstracts of all articles. All abstracts that reported sufficient information according to the inclusion and exclusion criteria were selected. The eligibility step were excluded studies that do not describe the quantity of cells used to induce solid tumor. At the end of assessment, forty studies meet the inclusion and exclusion criteria and were evaluated (Figure 1). Were included a few studies that do not meet the criteria, but they are the basis for this theme. 

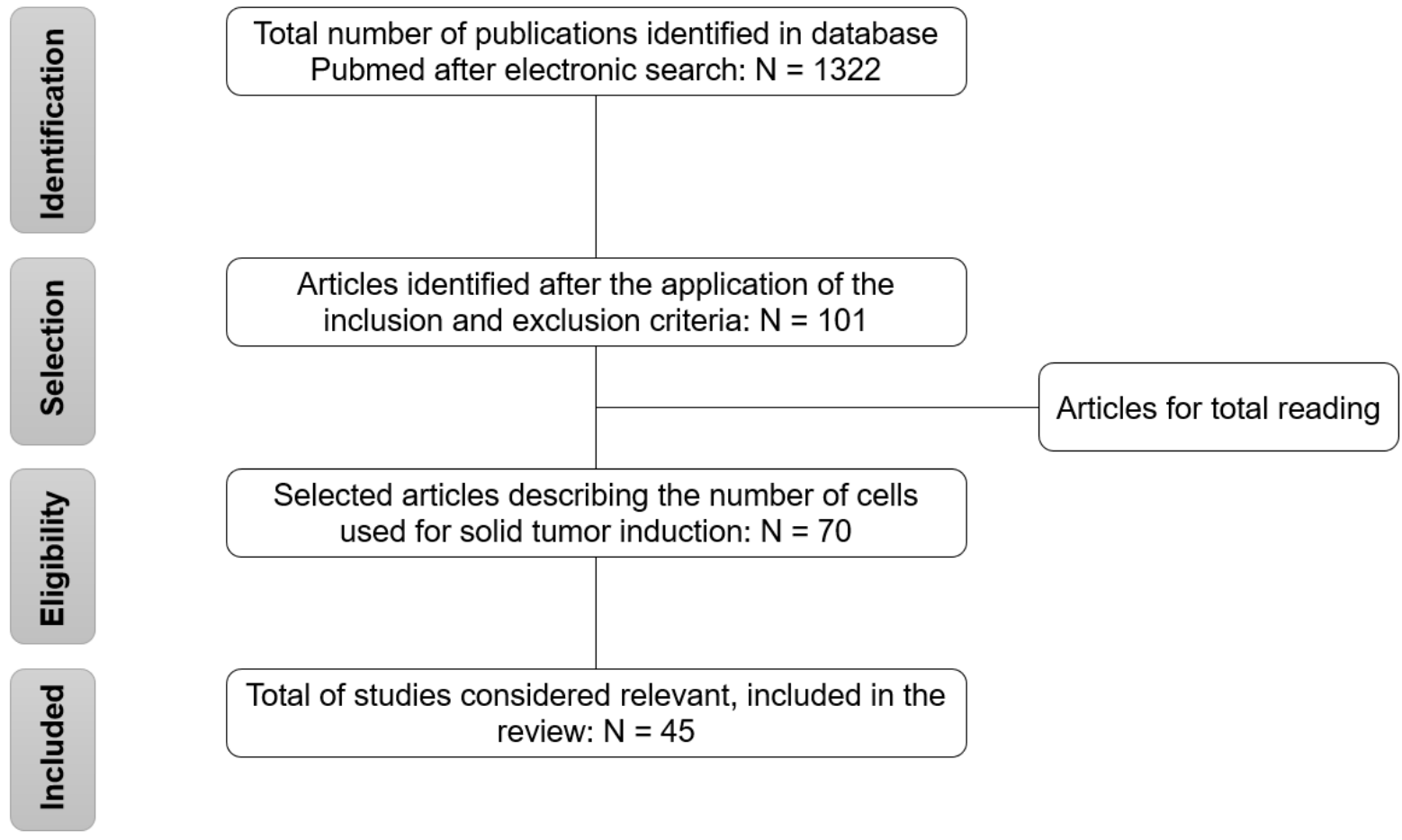

Figure 1. Flowchart of the selection of articles used in this review

\section{RESULTS}

At this research, were included 45 articles according to the selection criteria described at the material and methods section. In Table 1 are listed the selected articles to the review, with description of quantity of cells used and implantation sites of Walker-256 solid tumor.

Table 1. Site of implantation and inoculated number of cells for induction of solid tumor of Walker-256

\begin{tabular}{|c|c|c|c|}
\hline $\begin{array}{l}\text { Tumor } \\
\text { implantation } \\
\text { site }\end{array}$ & Objectives & $\begin{array}{c}\text { Inoculated } \\
\text { number (cells } \\
\text { / rat) }\end{array}$ & References \\
\hline \multirow[t]{4}{*}{ Flank } & $\begin{array}{l}\text { To investigate the effects of aerobic exercise training } \\
\text { starting at adolescence, on Walker } 256 \text { tumor growth } \\
\text { and insulin secretion in adult rats }\end{array}$ & $8 \times 10^{7}$ & $\begin{array}{l}\text { MOREIRA et } \\
\text { al., } 2018^{15}\end{array}$ \\
\hline & $\begin{array}{l}\text { To evaluate whether obese adult rats that were } \\
\text { chronically treated with an antidiabetic drug, } \\
\text { glibenclamide, exhibit resistance to rodent breast } \\
\text { carcinoma growth }\end{array}$ & $8 \times 10^{7}$ & $\begin{array}{l}\text { FRANCO et al., } \\
\qquad 2017^{16}\end{array}$ \\
\hline & $\begin{array}{l}\text { To identify mechanisms of inflammatory response in } \\
\text { atrophy in cancer cachexia }\end{array}$ & $2 \times 10^{7}$ & $\begin{array}{l}\text { HENRIQUES et } \\
\text { al., } 2017^{17}\end{array}$ \\
\hline & $\begin{array}{l}\text { To investigate the antitumor activity of the soluble } \\
\text { fraction of polysaccharides, extracted fromcabernet }\end{array}$ & $2 \times 10^{7}$ & $\begin{array}{l}\text { STIPP et al., } \\
\qquad 2017^{10}\end{array}$ \\
\hline
\end{tabular}


franc red wine, in Walker-256 tumor-bearing rats

To investigate the pioglitazone effects, isolated or

$8 \times 10^{7}$

SILVA et al., associated with insulin, on insulin resistance, $2017^{18}$ cachexia and metabolic disorders in cancer animal model

To evaluate the in vivo antitumor effects and toxicity $1 \times 10^{7}$ SOUZA et al., of a new $\mathrm{Ru}(\mathrm{II})$ compound, cis-(Ru[phen]2[ImH]2)2+ $2017^{14}$ (also called RuphenlmH [RuC]), against Walker-256 carcinosarcoma in rats

To analyse the modulatory effect of a leucine-rich diet CRUZ et al., on direct and indirect tumor-induced placental damage

To determine the effect of tumors on interstitial cells FRACARO et of Cajal in the rat jejunum and to investigate the effect al, $2016^{20}$ of $2 \%$ L-glutamine on interstitial cells of Cajal and tumor-induced changes

To assess the effect of endostatin combined with a small dose of $32 \mathrm{P}$-colloidal in vivo

GAO et al., $2016^{7}$

To assess antioxidant effects of açaí seed extract on anorexia-cachexia induced by Walker-256 tumor

To provide insight into adipocyte involvement in inflammation along the progression of cachexia

$2 \times 10^{7}$ et al., $2016^{21}$

To evaluate the metformin on Walker-256 tumor $1 \times 10^{6}$

OLIVEIRA et al. evolution and also on protein metabolism in gastrocnemius muscle and body composition

To evaluate whether leucine supplementation $2,5 \times 10^{6}$

TONETO et al., ameliorates cachexia in the heart $2016^{24}$

To evaluate whether a leucine-rich diet affects metabolomic derangements

$2,5 \times 10^{6}$

VIANA et al., $2016^{25}$

in serum and tumor tissues in tumor-bearing Walker-256 rats

To evaluate the effect of dietary supplementation with $8 \times 10^{7}$ VICENTINI et $20 \mathrm{~g} / \mathrm{kg} \mathrm{L}$-glutamine on the intrinsic innervation of the al., $2016^{26}$ enteric nervous system in healthy and Walker 256 tumor-bearing Wistar rats during the development of 
experimental cachexia

To investigate the pharmacokinetics profiles of

$1 \times 10$

FAN et al., ginsenoside $\mathrm{Rg}$ and ginsenoside $\mathrm{Rh}$ after oral $2016^{27}$ administration of pure ginsenoside $\mathrm{Rg}$ were administered, and compare the difference of the pharmacokinetics profiles between normal and Walker 256 tumorbearing rats

To investigate the effect of fish oil supplementation on BORGHETTI et apoptosis protein expression in Walker 256 tumor al, $2015^{28}$ bearing rats

To evaluate the in vivo antitumor actions and toxicity MARTINS et of the dichloromethane fraction of Moquiniastrum al., $2015^{13}$ polymorphum subsp. floccosum (formerly Gochnatia polymorpha ssp. floccosa), composed of sesquiterpene lactones, against Walker-256 carcinosarcoma in rats

To investigate the effects of celecoxib and ibuprofen, $8 \times 10^{7}$ SOUZA et al., $2015^{29}$ decreased gluconeogenesis observed in liver of Walker-256 tumor-bearing rats

To investigate the effect of a leucine-rich diet on

CRUZ et al., protein metabolism in the foetal gastrocnemius $2014^{30}$ muscles of tumor-bearing pregnant rats

To test the effect of metformin on the tumor growth in rats with metabolic syndrome

FRANCO et al., $2014^{31}$

To investigate the effect of fish oil supplementation on $3 \times 10^{7}$ BORGHETTI et tumor growth, cyclooxygenase 2, peroxisome al., $2013^{4}$ proliferator-activated receptor gamma, and RelA gene and protein expression in Walker 256 tumor-bearing rats

To evaluate gluconeogenesis from alanine, pyruvate $8 \times 10^{7}$ MOREIRA et and glycerol, and related metabolic parameters in al., $2013^{32}$ perfused liver from Walker-256 tumor-bearing rats on days 5,8 and 12 of tumor development

To investigate the effect of infliximab, an anti-tumor $8 \times 10^{7}$ MIKSZA et al., $2013^{12}$ 
progression of cachexia and several metabolic parameters affected by the Walker-256 tumor in rats

To describe effects of the resistance exercise training $3 \times 10^{7}$ DONATTO et upon adipose tissue inflammation in cachexia al., $2013^{33}$

To describe set point of weight loss and how the $2 \times 10^{7}$ BATISTA JR et different visceral adipose tissue depots contribute to al., $2012^{34}$ this symptom

To investigate the effects of electroacupuncture on $3 \times 10^{5}$ LIANG et al., mechanical allodynia and cellular immunity of $2018^{35}$ cancer-induced bone pain rats, and to further explore the potential mechanism

To investigate the role of NF-KB in CIBP by regulating MCP-1/chemokine CC motif receptor-2 (CCR2) $1 \times 10^{6}$ WANG et al., $2018^{36}$ signaling pathway.

To investigate whether P2Y12R is involved in the $2 \times 10^{7}$ LIU et al., establishment of cancer-induced bone pain model by $2017^{37}$ inoculating Walker 256 breast cancer cells in the tibia and to examine the effect of P2Y12R antagonist on spinal neuroimmune activity in a cancer-induced bone pain model

To investigate the role of Suppressor of cytokine $4 \times 10^{5}$ WEI et al., signaling 3 in dorsal root ganglion in the development $2017^{38}$ of cancer-induced pain

To assess the antinociceptive effect of Tanshinone IIA on cancer-induced bone pain

HAO et al., $2016^{39}$

To investigate whether spinal CCR5 and its $1 \times 10^{5}$ HANG et al., downstream $\mathrm{PKC} Y$ pathway is involved in the $2016^{40}$ maintenance of cancer-induced bone pain

To investigate the mechanisms underlying the

SONG et al., anti-nociceptive effect of minocycline on bone cancer $2016^{9}$ pain in rats

To investigate whether the lysophosphatidic acid receptor 1 and Rho / ROCK signaling are involved in $2016^{41}$ cancer-induced bone pain

Create a viable prolonged treatment for bone cancer $5 \times 10^{5}$ $\mathrm{XU}$ et al., pain 
To determine the efficacy of a calpain inhibitor on vivo in intratibial tumor injected cancer-induced bone pain rats

Examine the potential of the spinal sigma- 1 receptor in the development of cancer-induced bone pain

Examine the potential role of the spinal PKA/CREB signaling pathway in the development of bone cancer pain

To investigate whether the chemokine receptor 5 and C-kinase receptor pathway is involved in the maintenance of cancer-induced bone pain

To investigate the effects of intrathecal injection with lipoxin and related analogues on cancer-induced bone pain in rats

To investigate the role of $\mathrm{c}$-jun $\mathrm{N}$-terminal kinase pathway in the spinal cord in cancer-induced bone pain bone resorption and behavioral responses to pain in

$1 \times 10^{5}$

ZHU et al., $2015^{43}$

$2 \times 10^{5}$

WU et al., $2016^{44}$

$1 \times 10^{5}$

HANG et al., $2013^{45}$

$1 \times 10^{5}$

HANG et al., $2013 b^{46}$

$1 \times 10^{8}$ $\mathrm{HU}$ et al., $2012^{47}$

$3,5 \times 10^{5}$

WANG et al., $2012^{48}$

GUI et al., $2015^{49}$

Femur telopeptide (NTx) can be used to predict the anti-nociceptive responses of zoledronic acid and paclitaxel on bone metastases in a rat model

Compare the effects of ibandronate and paclitaxel on bone structure and its mechanical properties and $2,5 \times 10^{6}$ CHUNG et al., $2015^{5}$ biochemical turnover in resorption markers using an immunocompetent Walker 256-Sprague-Dawley model, which was subjected to tumor-induced osteolysis.

Establish a model of femoral bone cancer $1 \times 10^{5}$ GUI et al., $2013^{50}$ $1 \times 10^{6}$ BRIGATTE et To investigate the effects of crotoxin on Walker 256 tumor growth, the pain symptoms associated al., $2016^{6}$ (hyperalgesia and allodynia), and participation of endogenous lipoxin

A4 


\section{DISCUSSION}

\section{History of Walker-256 tumor}

George Walker observed firstly in 1928 the Walker-256 tumor spontaneously in the region of mammary gland of a pregnant albino rat, which regressed completely during the lactation period. But it grew again, after the weaning of the offspring. Thus, this was the first researcher to perform the implant using these tumor cells, through fragmentation ${ }^{51}$.

Subsequently, the technique was improved and the tumor cell line is easily implantable, specific for mice and grows rapidly in the host animal. The cells are maintained in the laboratory by means of weekly passages into intraperitoneal cavity of rats, when necessary the solid tumor is induced by subcutaneous or muscle and become palpable about four days post-implant and can grow to a mean diameter of 20-30 mm within 8 days $4,13,23,27,52$.

\section{Cell maintenance}

Walker-256 tumor cells are maintained by weekly passages of the intraperitoneal cavity of rats of both sexes. After the intraperitoneal application the survival of animal is of seven days ${ }^{27}$. For this procedure it is necessary that the animal be anesthetized and subsequently submitted to euthanasia according to the ethical principles affirmed by the Brazilian College of Animal Experimentation ${ }^{53}$ and by the Declaration of the Rights of the Animals ${ }^{54}$.

After euthanasia, the cells are harvested from the abdominal cavity, centrifuged, resuspended in phosphate-saline buffered, saline solution or Hank's balanced saline solution and performed the cell viability test by the Trypan blue exclusion assay in Neubauer's chamber. Subsequently, the cells are inoculated into a second animal intraperitoneally, until the application the cells need to be refrigerated $6,10,27,31,44,45$.

The ascites tumor is neither visible nor palpable. The ascitic fluid is hemorrhagic, so some authors such as Martins et al. ${ }^{13}$ and Stipp et al. ${ }^{10}$ reported using the solution of ethylenediaminetetraacetic acid (EDTA) as anticoagulant in the collection because of the blood present.

Few studies describe the quantity of cells used for ascites tumor induction, among the 45 papers analyzed, only 10 cited the amount used. The most commonly used amounts were $1 \times 10^{7}(70 \%)$ and $2 \times 10^{7}(30 \%)$.

\section{Solid tumor implantation sites}

The implant is performed after the Trypan blue exclusion test in the Neubauer chamber. The cells are resuspended in phosphate-saline buffer, saline solution or Hank's balanced saline and applied at the sites determined by the studies ${ }^{6,10,13,27,45}$ added the antibiotic cell suspension (benzylpenicillin and benzetacil) in order to avoid microbial contamination.

It was observed in Table 1 that $58 \%(n=26)$ of the studies inoculated the cells in the flanks of the animals, 33\% $(n=15)$ in the tibia bone, $7 \%(n=3)$ in the femur and $2 \%(n=1)$ in the paw, using the subcutaneous via.

Tumors inoculated on the tibia and femur seek to elucidate the mechanisms and treatments related to cancer-induced bone pain. It was observed that the largest number of studies used the flank because it did not specify the primary site related to the human, it is worth mentioning that the implant is performed on both the right and left flanks (Figure 2). 


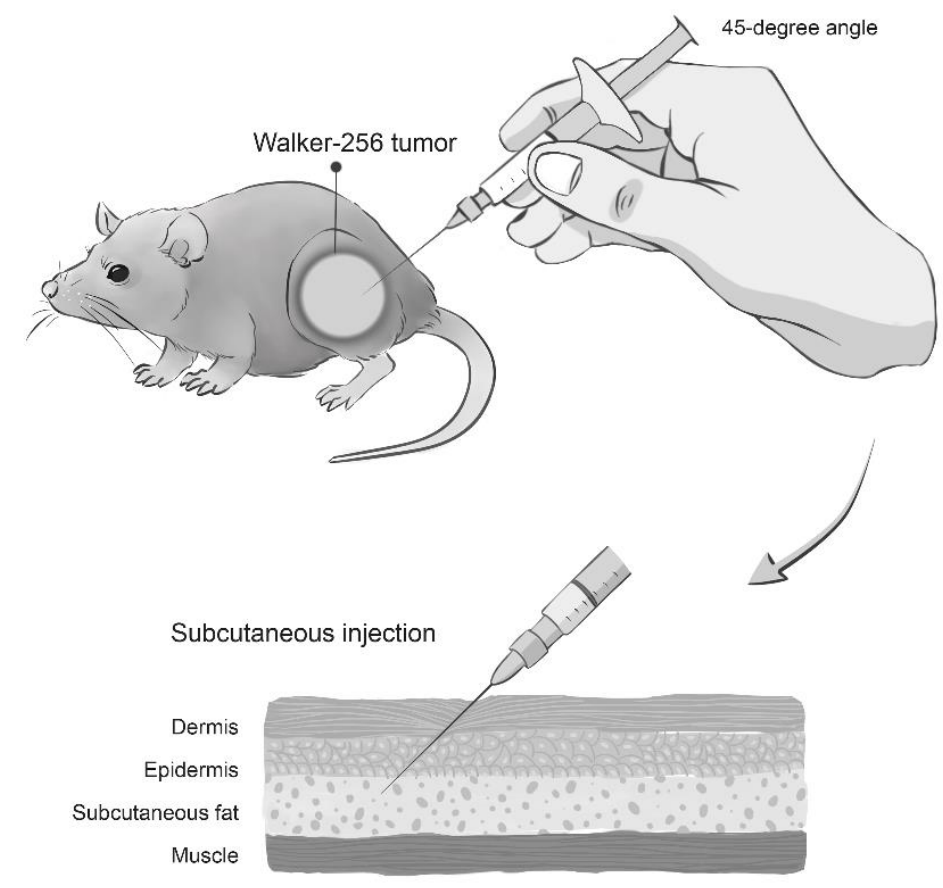

Figure 2. Implantation of Walker-256 tumor cells by subcutaneous injection into flank pathway for induction of solid tumor

\section{Cell inoculation for induction of solid tumor}

According to Table 1 it was observed that the main quantity of cells used were $8 \times 10^{7}$ $(20 \%), 1 \times 10^{5}(13 \%), 1 \times 10^{6}(11 \%)$ and $2 \times 10^{7}(11 \%)$. Thus, we observed that there is no consensus among the articles regarding the quantity of cells to be applied for the induction of solid tumors.

According to this review it was possible to verify that the experimental period was of 12 to 16 days, not obtaining a standard in the amount of days and dose for each site of implantation.

\section{CONCLUSION}

This review allowed to know the Walker-256 tumor and its peculiarities. Thus, we understood that for the ascites tumor induction the quantity $1 \times 10^{7}$ and $2 \times 10^{7}$ are used, according to the literature. It is also inferred that the main site of implantation of this cell line for induction of solid tumor is the flank and the amount of cells is not yet defined. However, the most used quantities are $8 \times 10^{7}$ and $1 \times 10^{5}$. Suggesting that this number may vary according to the aggressiveness of the cells and experimental design.

Funding: "This study was financed in part by the Coordenação de Aperfeiçoamento de Pessoal de Nível Superior - Brasil (CAPES) - Finance Code 001"

Conflicts of Interest: The authors declare no conflict of interest.

\section{REFERENCES}

1. Early cancer diagnosis saves lives, cuts treatment costs [http://www.who.int/mediacentre/news/releases/2017/early-cancer-costs/en/]. Genebra:World Health Organization. Updated in 3 February 2017 accessed in 19 november 2017. Available from: http://www.who.int/ 
2. Martin L, Birdsell L, Macdonald N, Reiman T, Clandinin MT, Mccargar LJ, et al. Cancer cachexia in the age of obesity: skeletal muscle depletion is a powerful prognostic factor, independent of body mass index. J Clin Oncol. 2013; 31: 1539-1547.

3. Barajas-Galindo DE, Vidal-Casariego A, Calleja-Fernández A, Hernández-Moreno A, Pintor De La Maza B, Pedraza-Lorenzo M, et al. Appetite disorders in cancer patients: Impact on nutritional status and quality of life. Appet. 2017; 114 (12): 23-27.

4. Borghetti G, Yamazaki RK, Coelho I, Pequito DCT, Schiessel DL, Kryczyk M, et al. Tumor growth reduction is regulated at the gene level in Walker 256 tumor-bearing rats supplemented with fish oil rich in EPA and DHA. Braz J Med Biol Res. 2013; 46 (8): 696-699.

5. Chung YS, Kang HC, Lee T. Comparative effects of ibandronate and paclitaxel on immunocompetent bone metastasis model. YMJ. 2015; 56 (6): 1643-1650.

6. Brigatte P, Faiad OJ, Nocelli RCF, Landgraf RG, Palma MS, Cury Y, et al. Walker 256 tumor growth suppression by crotoxin involves formyl peptide receptors and lipoxin A4. Mediators Inflamm. 2016; 8: 1-11.

7. Gao H, Zhu J, Li Y, Fu P, Shen B. Inhibitory effect of endostatin gene therapy combined with phosphorus-32 colloid on tumour growth in Wistar rats. Biosci Rep. 2016; 36 (3): 1-7.

8. Gonçalves M, Cappellari AR, Junior AAS, Marchi FO, Macchi FS, Antunes KH, et al. Effect of LPS on the Viability and proliferation of human oral and esophageal cancer cell lines. Braz. arch. biol. technol. 2016; 59: 1-10.

9. Song ZP, Xiong BR, Guan XH, Cao F, Manyande A, Zhou YQ, et al. Minocycline attenuates bone cancer pain in rats by inhibiting NF-KB in spinal astrocytes. Acta Pharmacol Sin. 2016; 37 (6): 753-762.

10. Stipp MC, Bezerra IL, Corso CR, Livero FAR, Lomba LA, Caillot ARC, et al. Necroptosis mediates the antineoplastic effects of the soluble fractionof polysaccharide from red wine in Walker-256 tumor-bearing rats. Carbohydr Polym. 2017; 160: 123-133.

11. Fallah S, Hajihassan Z, Zarkar N, Rabbani- Chadegani A, Mohammadnejad J, Hajimirzamohammad M. Evaluation of anticancer activity of extracted flavonoids from morus alba leaves and its interaction with DNA. Braz. Arch. Biol. Technol. 2018; 61: 1-7.

12. Miksza DR, Souza CO, Morais H, Rocha AF, Borba-Murad GR, Bazotte RB, et al. Effect of infliximab on metabolic disorders induced by Walker-256 tumor in rats. Pharmacol Rep. 2013; 65 (4): 960-969.

13. Martins GG, Lívero FAR. Stolf AM, Kopruszinski CM, Cardoso CC, Beltrame OC, et al. Sesquiterpene lactones of Moquiniastrum polymorphum subsp. Floccosum have antineoplastic effects in Walker-256 tumor-bearing rats. Chem Biol Interact. 2015; 228: 46-56.

14. Souza CEA, Alves de Souza HM, Stipp MC, Corso CR, Galindo CM, Cardoso CR, et al. Ruthenium complex exerts antineoplastic effects that are mediated by oxidative stress without inducing toxicity in Walker-256 tumor-bearing rats. Free Radic Biol Med. 2017; 110: 228-239.

15. Moreira, VM, Franco CCS, Prates KV, Gomes RM, Moraes AMP, Ribeiro TA, et al. Aerobic Exercise Training Attenuates Tumor Growth and Reduces Insulin Secretion in Walker 256 Tumor-Bearing Rats. Front Physiol. 2018; 9: 465.

16. Franco CCS, Previate C, de Barros Machado KG, Piovan S, Miranda RA, Prates KV, et al. Chronic Glibenclamide Treatment Attenuates Walker-256 Tumour Growth in Prediabetic Obese Rats. Cell Physiol Biochem. 2017; 42 (1): 81-90.

17. Henriques FS, Sertié FAL, Franco FO, Knobl P, Neves RX, Andreotti S, et al. Early suppression of adipocyte lipid turnover induces immunometabolic modulation in cancer cachexia syndrome. FASEB J. 2017; 31 (5): 1976-1986.

18. Silva FF, Ortiz-Silva M, Galia WBS, Cassolla P, Graciano MFR, Zaia CTBV, et al. Pioglitazone improves insulin sensitivity and reduces weight loss in Walker-256 tumor-bearing rats. Life Sci. 2017; 15: 68-74.

19. Cruz BLG, Silva PC, Tomasin R, Oliveira AG, Viana LR, Salomao EM, et al. Dietary leucine supplementation minimizes tumour-induced damage in placental tissues of pregnant, tumour-bearing rats. BMC. 2016; 16 (58): 1-13. 
20. Fracaro L, Frez FCV, Silva BC, Vicentini GE, de Souza SRG, Martins HÁ, et al. Walker 256 tumor-bearing rats demonstrate altered interstitial cells of cajal effects on icc in the walker 256 tumor model. Neurogastroenterol Motil. 2016; 28 (1): 101-115.

21. Nascimento VHN, Lima CS, Paixão JTC, Freitas JJS, Kietzer KS. Antioxidant effects of açaí seed (Euterpe oleracea) in anorexia-cachexia syndrome induced by Walker-256 tumor. Acta Cir Bras. 2016; 31 (9): 597-601.

22. Neves RX, Rosa-Neto JC, Yamashita AS, Matos-Neto EM, Riccardi DMR, Lira FS, et al. White adipose tissue cells and the progression of cachexia: inflammatory pathways. J Cachexia Sarcopenia Muscle. 2016; 7 (2): 193-203.

23. Oliveira AG, Gomes-Marcondes MCC. Metformin treatment modulates the tumour-induced wasting effects in muscle protein metabolism minimising the cachexia in tumour-bearing rats. BMC. 2016; 16 (418): 1-10.

24. Toneto AT, Ramos LAF, Salomão EM, Tomasin R, Aereas MA, Gomes-Marcondes MCC. Nutritional leucine supplementation attenuates cardiac failure in tumour-bearing cachectic animals. J Cachexia Sarcopenia Muscle. 2016; 7 (5): 577-586.

25. Viana LR, Canevarolo R, Luiz ACP, Soares RF, Lubaczeuski C, Zeri ACM, et al. Leucine-rich diet alters the $1 \mathrm{H}-\mathrm{NMR}$ based metabolomic profile without changing the Walker-256 tumour mass in rats. BMC. 2016; 16 (1): 1-14.

26. Vicentini GE, Fracaro L, de Souza SRG, Martins HA, Guarnier FA, Zanoni JN. Experimental cancer cachexia changes neuron numbers and peptide levels in the intestine: partial protective effects after dietary supplementation with I-glutamine. Plos one. 2016; 16 (9): 1-23.

27. Fan H, Xiaoling S, Yaliu S, Mingming L, Xue F, Xiansheng M, Li F. Comparative pharmacokinetics of ginsenoside $\mathrm{rg}$ and ginsenoside $\mathrm{rh}$ after oral administration of ginsenoside rg in normal and walker 256 tumor bearing rats. Pharmacogn Mag. 2016; 12 (45): 21-24.

28. Borghetti G, Yamaguchi AA, Aikawa J, Yamazaki RK, Brito GAP, Fernandes LC. Fish oil administration mediates apoptosis of Walker 256 tumor cells by modulation of p53, Bcl-2, caspase-7 and caspase-3 protein expression. Lipids Health Dis. 2015; 14 (94): 1-5.

29. Souza CO, Kurautia MA, Silva FF, Morais H, Curi R, Hirabara SM, et al. Celecoxib and ibuprofen restore the ATP content and the gluconeogenesis activity in the liver of walker-256 tumor-bearing rats. Cell Physiol Biochem. 2015; 36 (4): 1659-1669.

30. Cruz B, Gomes-Marcondes MCC. Leucine-rich diet supplementation modulates foetal muscle protein metabolism impaired by Walker-256 tumour. Reprod Biol Endocrinol. 2014; 12 (2): 1-10.

31. Franco CCS, Miranda RA, Oliveira JC, Barella LF, Agostinho AR, Prates KV, et al. Protective effect of metformin against walker 256 tumor growth is not dependent on metabolism improvement. Cell Physiol Biochem. 2014; 34 (6): 1920-1932.

32. Moreira CCL, Cassolla P, Dornellas APS, Morais H, Souza CO, Borba-Murad GR, et al. Changes in liver gluconeogenesis during the development of Walker-256 tumour in rats. Int. J. Exp. Path. 2013; 94 (1): 47-55.

33. Donatto FF, Neves RX, Rosa FO, Camargo RG, Ribeiro H, Matos-Neto EM, et al. Resistance exercise modulates lipid plasma profile and cytokine content in the adipose tissue of tumour-bearing rats. Cytokine. 2013; 61 (2): 426-432.

34. Batista Jr ML, Neves RX, Peres SB, Yamashita AS, Shida CS, Farmer SR, et al. Heterogeneous time-dependent response of adipose tissue during the development of cancer cachexia. $\mathrm{J}$ Endocrinol. 2012; 215 (3): 363-373.

35. Liang Y, Du JY, Fang JF, Fang RY, Zhou J, Shao XM, et al. Alleviating Mechanical Allodynia and Modulating Cellular Immunity Contribute to Electroacupuncture's Dual Effect on Bone Cancer Pain. Integr Cancer Ther. 2018; 17 (2): 401-410.

36. Wang Y, Ni H, Li H, Deng H, Xu LS, Xu S, et al. Nuclear factor kappa B regulated monocyte chemoattractant protein-1/chemokine CC motif receptor-2 expressing in spinal cord contributes to the maintenance of cancer-induced bone pain in rats. Mol Pain. 2018; 14: 1-17.

37. Liu M, Yao M, Wang H, Xu L, Zheng Y, Huang B, et al. P2Y12 receptor-mediated activation of spinal microglia and p38MAPK pathway contribute to cancer-induced bone pain. J Pain Res. 2017; 10: 417-426. 
38. Wei J, Li M, Wang D, Zhu H, Kong X, Wang S, et al. Overexpression of suppressor of cytokine signaling 3 in dorsal root ganglion attenuates cancer-induced pain in rats. Mol Pain. 2017; 13: $1-12$.

39. Hao W, Chen L, Wu L, Yang F, Niu J, Kaye AD, et al. Tanshinone IIA Exerts an Antinociceptive Effect in Rats with Cancer-induced Bone Pain. Pain Physician. 2016; 19 (7): 465-476

40. Hang LH, Li SN, Dan X, Shu WW, Luo H, Shao DH. Involvement of spinal CCR5/PKCГ signaling pathway in the maintenance of cancer-induced bone pain. Neurochem Res. 2016; 42 (2): 563-571.

41. Pan R, Di H, Zhang J, Huang Z, Sun $Y$, Yu W, et al. Inducible lentivirus-mediated sirna against TLR4 reduces nociception in a rat model of bone cancer pain. Mediators Inflamm. 2016; 1: 1-7.

42. Xu JY, Jiang Y, Liu W, Huang YG. Calpain inhibitor reduces cancer-induced bone pain possibly through inhibition of osteoclastogenesis in rat cancer-induced bone pain model. Chin Med J. 2015; 128 (8): 1102-1107.

43. Zhu S, Wang C, Han Y, Song C, Hu X, Liu Y. Sigma-1 receptor antagonist bd1047 reduces mechanical allodynia in a rat model of bone cancer pain through the inhibition of spinal NR1 phosphorylation and microglia activation. Mediators Inflamm. 2015; 1: 1-11.

44. Wu JX, Yuan XM,Wang Q, Wei W, Xu MY. Rho/ROCK acts downstream of lysophosphatidic acid receptor 1 in modulating P2X3 receptor-mediated bone cancer pain in rats. Mol Pain. 2016; 12: $1-10$.

45. Hang LH, Yang JP, Shao DH, Chen Z, Wang $\mathrm{H}$. Involvement of spinal PKA/CREB signaling pathway in the development of bone cancer pain. Pharmacol Rep. 2013; 65 (3): 710-716.

46. Hang LH, Shao DH, Chen Z, Chen YF, Shu WW, Zhao ZG. Involvement of spinal cc chemokine ligand 5 in the development of bone cancer pain in rats. Basic Clin Pharmacol Toxicol. 2013; 113 (5): 325-328.

47. Hu S, Ying QLM, Wang J, Wang ZF, Mi ZH, Wang XW, et al. Lipoxins and aspirin-triggered lipoxin alleviate bone cancer pain in association with suppressing expression of spinal proinflammatory cytokines. J Neuroinflammation. 2012; 26 (9): 1-12.

48. Wang XW, Hu S, Ying QLM, Li Q, Yang CJ, Zhang H, et al. Activation of C-jun N-terminal kinase in spinal cord contributes to breast cancer induced bone pain in rats. Mol Brain. 2012; 5 (21): 1-7.

49. Gui Q, Xu C, Li D, Zhuang L, Xia S, Yu S. Urinary N telopeptide levels in predicting the anti-nociceptive responses of zoledronic acid and paclitaxel in a rat model of bone metastases. Mol Med Rep. 2015; 12 (3): 4243-4249.

50. Gui Q, Xu C, Zhuang L, Xia S, Chen Y, Peng P. et al. A new rat model of bone cancer pain produced by rat breast cancer cells implantation of the shaft of femur at the third trochanter level. Cancer Biol Ther. 2013; 14 (2): 193-199.

51. Earle WR. A study of the Walker rat mammary carcinoma 256: in vivo and in vitro. Am J Cancer. 1935; 24: 566-612.

52. Morrison SD. Feeding response to change in absorbable food fraction during growth of Walker 256 carcinosarcoma. Cancer Res. 1972; 32 (5): 968-972.

53. Ethical principles in animal experimentation [http://www.cobea.org.br/etica.htm\#3]. Brasília:Brazilian College of Animal Experimentation. Accessed in 20 march 2018. Available from: http://www.cobea.org.br/etica.htm\#3

54. Universal declaration of animal rights [https://constitutii.files.wordpress.com/2016/06/file-id-607.pdf]. Bruxelas:United Nations Educational, Scientific and Cultural Organization. Updated in 15 October 1978 accessed in 20 march 2018. Available from: https://constitutii.files.wordpress.com/2016/06/file-id-607.pdf 